\title{
ANALISIS KESIAPAN PEMERINTAH DAERAH DALAM MENERAPKAN STANDAR AKUNTANSI PEMERINTAHAN BERBASIS AKRUAL DAN DAMPAKNYA TERHADAP SUMBER DAYA MANUSIA PADA PEMERINTAH KOTA BITUNG
}

\author{
Greaty Prilen Humiang \\ David P.E. Saerang \\ Herman Karamoy
}

(email: greatyhumiang91@ yahoo.com)

\begin{abstract}
This study aims to determine the readiness of the government of Bitung in implementing accrualbased government accounting standards. Data was collected by observation at every SKPD in Bitung City Government followed in-depth interviews with key informants. The data collected was analyzed by qualitative methods. Then based on interviews (Focus Group Discussion) drawn conclusions indicate that Bitung City Government was ready to apply Accrual Based Government Accounting Standards. This is supported by the Government regulations which require to all local governments, including the city of Bitung in applying Accrual Based Government Accounting Standards, as well as Bitung City Government has issued the relevant mayor Accounting Policies in Bitung. Other things that support the readiness of the implementation of Accrual Based Accounting Standards, namely; development of human resources employee, committed leader who supports the changes later infromasi facilities and infrastructure systems are adequate and can accommodate Accrual Based Accounting Standards.
\end{abstract} Keywords: government accounting standards, the accrual basis, the government's readiness area

\section{PENDAHULUAN}

\subsection{Latar Belakang}

Salah satu misi pemerintahan Indonesia saat ini adalah mewujudkan pemerintahan yang bersih. Semakin meningkatnya tuntutan pelaksanaan pengelolaan keuangan negara yang transparan dan akuntabel mendorong pemerintah untuk terus berupaya memperbaiki sistem akuntansi yang digunakan. Sistem akuntansi berbasis akrual menjadi isu yang sangat penting di era reformasi untuk menciptakan good government governance.

Upaya konkrit dalam mewujudkan transparansi dan akuntabilitas di lingkungan pemerintah daerah mengharuskan setiap pengelola keuangan daerah untuk menyampaikan laporan pertanggungjawaban pengelolaan keuangan daerah. Laporan pertanggungjawaban pengelolaan keuangan daerah atau Laporan Keuangan Pemerintah Daerah adalah bentuk pertanggungjawaban sebagaimana ditetapkan dalam Pasal 30, Pasal 31, dan Pasal 32 Undang-undang Nomor 17 Tahun 2003 tentang Keuangan Negara, Pasal 55 ayat (2) dan ayat (3), serta Pasal 56 ayat (3) Undang-undang Nomor 1 Tahun 2004 tentang Perbendaharaan Negara. Pemerintah Pusat, Kementerian, Lembaga dan Pemerintah daerah berkewajiban untuk menyusun Laporan Keuangan Laporan keuangan merupakan sumber informasi finansial yang memiliki pengaruh yang sangat besar terhadap kualitas keputusan yang dihasilkan. Informasi keuangan yang terdapat dalam laporan keuangan tersebut digunakan oleh pihak-pihak yang berkepentingan, baik internal maupun eksternal.

Perubahan perlakuan akuntansi pemerintah menuju basis akrual akan membawa dampak/implikasi walau sekecil apapun. Perubahan menuju arah yang lebih baik ini bukan berarti hadir tanpa masalah. Pertanyaan pro-kontra mengenai kesiapan pemerintah daerah mengimplementasikan SAP berbasis akrual ini akan terus timbul. Masalah yang paling mendasar adalah terkait sumber daya manusia oleh pemerintah daerah yang kurang memadai dalam pengelolaan keuangan. Tentunya hal ini sangatlah mempengaruhi kesiapan pemerintah daerah tersebut dalam menerapkan sistem akuntansi berbasis akrual. Selanjutnya, infrastruktur yang dibutuhkan dalam penerapan akuntansi berbasis akrual penuh membutuhkan sumber daya teknologi informasi yang lebih tinggi. 
Berdasarkan fakta di atas, maka akan dilakukan analisis mengenai persiapan pemerintah Daerah dalam hal ini penelitian akan dilaksanakan di Pemerintah Kota Bitung Provinsi Sulawesi Utara terkait dengan kesiapan penerapan Standar Akuntansi Pemerintahan Berbasis Akrual dalam penyusunan laporan keuangannya. Selanjutnya, akan dilakukan identifikasi kemungkinan kendala yang dihadapi oleh pemerintah Kota Bitung dalam menerapkan basis akrual dengan menguraikan pengaruh budaya organisasi dan sikap individu dengan adanya perubahan standar akuntansi pemerintahan kas menuju akrual menjadi standar akuntansi pemerintahan berbasis akrual serta dampaknya setelah penerapan Standar Akuntansi Pemerintahan berbasis akrual terhadap peningkatan pengembangan dalam hal ini pengembangan Sumber Daya Manusia di Kota Bitung. Berdasarkan hal-hal yang telah diuraikan diatas maka judul yang diangkat dalam penelitian ini adalah "Analisis kesiapan pemerintah daerah dalam menerapkan standar akuntansi pemerintahan berbasis akrual serta dampaknya terhadap pengembangan sumber daya manusia pada pemerintah kota Bitung”.

\subsection{Rumusan Masalah}

Setelah ditetapkannya Peraturan Pemerintah Nomor 71 tahun 2010 tentang Penerapan Standar Akuntansi Pemerintahan (SAP) berbasis akrual, maka diwajibkan seluruh pemerintah daerah untuk dapat mulai menerapkan SAP berbasis akrual. Tentunya hal ini mendorong pemerintah baik yang di pusat maupun daerah untuk melakukan berbagai persiapan. Satu diantaranya yaitu menyiapkan Sumber Daya Manusia yang kompeten dibidangnya. Dengan demikian, perumusan masalah yang diangkat dalam penelitian ini adalah bagaimana kesiapan pemerintah daerah dalam menerapkan standar akuntansi pemerintahan berbasis akrual serta dampaknya terhadap pengembangan sumber daya manusia pada pemerintah kota Bitung ?.

\subsection{Tujuan Penelitian}

Tujuan dari penelitian ini adalah untuk mengetahui kesiapan pemerintah Kota Bitung dalam menerapkan Standar Akuntansi Pemerintahan berdasarkan Peraturan Pemerintah nomor 71 tahun 2010 mengenai standar akuntansi pemerintahan berbasis akrual sehubungan dengan Sumber Daya Manusia dalam mengimplementasi Standar Akuntansi Pemerintahan Berbasis Akrual .

\subsection{Manfaat Penelitian}

\section{Bagi Peneliti}

Sebagai salah satu syarat untuk mendapatkan gelar magister akuntansi selain itu penulis juga tertarik untuk meneliti tentang sejauh mana kesiapan pemerintah daerah dalam menerapkan Standar Akuntansi Pemerintahan dalam hal ini Peraturan Pemerintah Nomor 71 tahun 2010. Sehingga menambah pengetahuan peneliti mengenai Penerapan Standar Akuntansi Pemerintahan Berbasis Akrual khususnya dalam Instansi Pemerintah.

\section{Bagi Akademis}

Sebagai esensi referensi untuk penelitian-penelitian selanjutnya dan diharapkan dapat menambah wawasan kepada akademisi mengenai analisa kesiapan Instansi Pemerintah dalam menerapkan Standar Akuntansi Pemerintahan Berbasis Akrual.

\section{Bagi Pemerintah}

Sebagai sumber informasi dan diharapkan dapat memberikan masukkan terhadap pemerintahan kota Bitung dan semua instansi pemerintahan yang akan menggunakan Standar Akuntansi Pemerintahan Berbasis Akrual .

\section{I.I TINJAUAN PUSTAKA}

\subsection{Standar Akuntansi Pemerintahan}

Krisis ekonomi Indonesia tahun 1997, diikuti oleh era reformasi tahun1998, pelaksanaan otonomi daerah tahun 1999 sering disebut-sebut sebagai pemicudari reformasi keuangan daan akuntansi pemerintahan. Mahmudi dalam Bastian (2006), menyebutkan bahwa perjalanan manajemen keuangan Negara/Daerah diIndonesia dapat dibagi dalam tiga fase yaitu:

1) Era sebelum otonomi daerah, 
2) Eratransisi otonomi (reformasi tahap 1), dan

3) Era pascatransisi (reformasi tahap 2).

\subsubsection{Pengertian Standar Akuntansi Pemerintahan}

Standar Akuntansi Pemerintahan (SAP) ditetapkan dengan Peraturan Pemerintah Nomor 71 Tahun 2010 sebagai pengganti Peraturan Pemerintah Nomor 24 Tahun 2005. SAP dinyatakan dalam bentuk Pernyataan Standar Akuntansi Pemerintahan (PSAP), dilengkapi dengan Pengantar Standar Akuntansi Pemerintahan dan disusun mengacu kepada Kerangka Konseptual Akuntansi Pemerintahan. SAP harus digunakan sebagai acuan dalam menyusun laporan keuangan pemerintah, baik Pemerintah Pusat maupun pemerintah daerah.

Dari beberapa pengertian diatas dapat disimpulkan bahwa Standar Akuntansi Pemerintahan, yang selanjutnya disingkat SAP, adalah prinsip-prinsip akuntansi yang diterapkan dalam menyusun dan menyajikan laporan keuangan baik pemerintah pusat maupun pemerintah daerah dalam rangka mencapai transparansi dan akuntabilitas.

\subsubsection{Standar Akuntansi Pemerintahan Berbasis Akrual}

Salah satu hasil studi yang dilakukan oleh IFAC Public Sector Committee (2002) menyatakan bahwa pelaporan berbasis akrual bermanfaat dalam mengevaluasi kinerja pemerintah terkait biaya jasa layanan, efisiensi, dan pencapaian tujuan. Dengan pelaporan berbasis akrual, pengguna dapat mengidentifikasi posisi keuangan pemerintah dan perubahannya, bagaimana pemerintah mendanai kegiatannya sesuai dengan kemampuan pendanaannya sehingga dapat diukur kapasitas pemerintah yang sebenarnya. Akuntansi pemerintah berbasis akrual juga memungkinkan pemerintah untuk mengidentifikasi kesempatan dalam menggunakan sumber daya masa depan dan mewujudkan pengelolaan yang baik atas sumber daya tersebut.

\subsubsection{Tantangan Penerapan Akuntansi Berbasis Akrual di Pemerintahan Indonesia}

Penerapan akuntansi berbasis akrual di pemerintahan Indonesia sejatinya sudah harus dilaksanakan sejak tahun 2008 sesuai amanat Undang-Undang Nomor 17 Tahun 2003 tentang Keuangan Negara dan Undang-Undang Nomor 1 Tahun 2004 tentang Perbendaharaan Negara. Dalam UndangUndang Nomor 17 Tahun 2004 pasal 36 ayat 1 menyatakan:

"Ketentuan mengenai pengakuan dan pengukuran pendapatan dan belanja berbasis akrual sebagaimana dimaksud dalam pasal 1 angka 13, 14, 15, dan 16 undang-undang ini dilaksanakan selambat-lambatnya dalam 5 (lima) tahun."

Begitu juga dengan Undang-Undang Nomor 1 Tahun 2004 tentang Perbendaharaan Negara pada pasal 70 ayat 2 dinyatakan:

"Ketentuan mengenai pengakuan dan pengukuran pendapatan dan belanja berbasis akrual sebagaimana dimaksud dalam pasal 12 dan pasal 13 undang-undang ini dilaksanakan selambat-lambatnya pada tahun anggaran 2008."

Namun, pada kenyataannya sampai sekarang penerapan akuntansi berbasis akrual tersebut belum terealisasi dengan maksimal, walaupun peraturan tentang standar akuntansi akrual telah diterbitkan. Hal ini merupakan tantangan besar bagi Pemerintah dan harus dilakukan secara hati-hati dengan persiapan yang matang dan terstruktur.

Menurut Simanjuntak (2010) dan Bastian (2006) beberapa tantangan penerapan akuntansi berbasis akrual di pemerintahan Indonesia adalah sebagai berikut:

1. Sistem Akuntansi dan Information Technology (IT) Based System

Adanya kompleksitas implementasi akuntansi berbasis akrual, dapat dipastikan bahwa penerapan akuntansi berbasis akrual di lingkungan pemerintahan memerlukan sistem akuntansi dan IT based system yang lebih rumit. Selain itu perlu juga dibangun sistem pengendalian intern yang memadai untuk memberikan keyakinan memadai atas tercapainya tujuan organisasi melalui kegiatan yang efektif dan efisien, keandalan pelaporan keuangan, pengamanan aset negara, dan ketaatan terhadap peraturan 
perundang-undangan. Hal tersebut telah diamanatkan oleh Undang-Undang No 1 tahun 2004 pasal 58 ayat 1 yang menyatakan:

"Dalam rangka meningkatkan kinerja, transparansi dan akuntabilitas pengelolaan keuangan negara, Presiden selaku Kepala Pemerintah mengatur dan menyelenggarakan Sistem Pengendalian Intern di lingkungan pemerintahan secara menyeluruh."

\section{Komitmen dari Pimpinan}

Dukungan yang kuat dari pimpinan merupakan kunci keberhasilan dari suatu perubahan. Salah satu penyebab kelemahan penyusunan Laporan Keuangan pada beberapa Kementerian/Lembaga adalah lemahnya komitmen pimpinan satuan kerja khususnya Satuan Kerja Perangkat Daerah (SKPD) penerima dana Dekonsentrasi/Tugas Pembantuan. Diundangkannya tiga paket keuangan negara serta undangundang pemerintahan daerah menunjukkan keinginan yang kuat dari pihak eksekutif dan legislatif untuk memperbaiki sistem keuangan negara, termasuk perbaikan atas akuntansi pemerintahan, yang menjadi ujian sekarang adalah peningkatan kualitas produk akuntansi pemerintahan dalam pencatatan dan pelaporan oleh kementerian/lembaga di pemerintah pusat dan dinas/unit untuk pemerintah daerah. Sistem akuntansi pemerintah pusat mengacu pada pedoman yang disusun oleh menteri keuangan. Sistem akuntansi pemerintah daerah ditetapkan oleh Gubernur/Bupati/Walikota dengan mengacu pada peraturan daerah tentang pengelolaan keuangan daerah. Sistem akuntansi pemerintah pusat dan sistem akuntansi pemerintah daerah disusun dengan mengacu pada Standar Akuntansi Pemerintahan (SAP). Kejelasan perundang-undangan mendorong penerapan akuntansi pemerintahan dan memberikan dukungan yang kuat bagi para pimpinan kementerian/lembaga di pusat dan Gubernur/Bupati/Walikota di daerah.

\section{Tersedianya Sumber Daya Manusia (SDM) yang Kompeten}

Laporan keuangan diwajibkan untuk disusun secara tertib dan disampaikan masing-masing oleh pemerintah pusat dan daerah kepada Badan Pemeriksa Keuangan (BPK) selambatnya tiga bulan setelah tahun anggaran berakhir. Selanjutnya, selambatnya enam bulan setelah tahun anggaran berakhir, laporan keuangan yang telah diperiksa oleh BPK tadi diserahkan oleh Pemerintah Pusat kepada DPR dan oleh Pemerintah Daerah kepada DPRD. Penyiapan dan penyusunan laporan keuangan tersebut memerlukan SDM yang menguasai akuntansi pemerintahan.

Pada saat ini, kebutuhan tersebut sangat terasa dengan semakin kuatnya upaya untuk menerapkan akuntansi pemerintahan berbasis akrual. Untuk itu, pemerintah pusat dan daerah perlu secara serius menyusun perencanaan SDM di bidang akuntansi pemerintahan. Termasuk di dalamnya memberikan sistem insentif dan remunerasi yang memadai untuk mencegah timbulnya praktik korupsi, kolusi, dan nepotisme $(\mathrm{KKN})$ oleh SDM yang terkait dengan akuntansi pemerintahan. Di samping itu, peran dari perguruan tinggi dan organisasi profesi tidak kalah pentingnya untuk memenuhi kebutuhan Akan SDM yang kompeten di bidang akuntansi pemerintahan.

\section{Lingkungan/Masyarakat}

Apresiasi dari masyarakat sangat diperlukan untuk mendukung keberhasilan penerapan akuntansi pemerintahan. Masyarakat perlu didorong untuk mampu memahami laporan keuangan pemerintah, sehingga dapat mengetahui dan memahami penggunaan atas peneriamaan pajak yang diperoleh dari masyarakat maupun pengalokasian sumber daya yang ada. Dengan dukungan yang positif, masyarakat mendorong pemerintah untuk lebih transparan dan akuntabel dalam menjalankan kebijakannya. Oleh karena itu dalam penelitian yang akan dilaksanakan menyangkut dengan kesiapan pemerintah daerah dalam menerapkan standar akuntansi berbasis akrual ada 3 indikator yang akan diteliti yaitu Komitmen pimpinan, Sumber Daya Manusia, Sarana/prasaran sistem informasi.

\subsubsection{Implementasi Konsep Value For Money}

Implementasi konsep value for money pada organisasi sektor publik perlu dilakukan seiring dengan meningkatnya tuntutan akuntabilitas publik dan pelaksanaan good governance. Implementasi konsep tersebut diyakini dapat memperbaiki akuntabilitas sektor publik dan memperbaiki kinerja sektor publik 
dengan meningkatkan efektivitas layanan publik, meningkatkan mutu layanan publik, menurunkan biaya layanan publik karena hilangnya inefisiensi, dan meningkatkan kesadaran akan penggunaan uang publik.

Value for money merupakan konsep pengelolaan organisasi sektor publik yang mendasarkan pada tiga elemen utama, yaitu: ekonomi, efisiensi, dan efektivitas.

1. Ekonomi

Pemerolehan input dengan kualitas dan kuantitas tertentu pada harga yang terendah. Ekonomi merupakan perbandingan input dengan input value yang dinyatakan dalam satuan moneter.

2. Efisiensi

Pencapaian output yang maksimum dengan input tertentu atau penggunaan input yang rendah untuk mencapai output tertentu. Efisiensi merupakan perbandingan output/input yang dikaitkan dengan standard kinerja atau target yang telah ditetapkan.

3. Efektivitas

Tingkat pencapaian hasil program dengan target yang ditetapkan. Secara sederhana efektivitas merupakan perbandingan outcome dengan output.

Ketiga hal tersebut merupakan elemen pokok value for money, namun beberapa sumber berpendapat bahwa ke tiga elemen saja belum cukup .Perlu ditambah dua elemen lain yaitu :

1. Equity

Kesempatan sosial yang sama untuk memperoleh pelayanan publik.

2. Equality

Pemerataan/kesetaraan penggunaan dana publik dilakukan secara merata.

Manfaat Implementasi Konsep Value for Money adalah seagai berikut:

1. Meningkatan efektivitas pelayanan publik, dalam arti pelayanan yang diberikan tepat sasaran.

2. Meningkatkan mutu pelayanan publik

3. Menurunkan biaya pelayanan publik karena hilangnya inefisiensi dan terjadinya penghematan dalam penggunan input

4. Alokasi belanja yang lebih berorientasi pada kepentingan publik

5. Meningkatkan kesadaran akan uang publik (public costs awareness) sebagai akar pelaksanaan akuntanbilitas public

Tujuan yang dikehendaki terkait pelaksanaan value for money adalah sebagai berikut:

1. Ekonomi: hemat cermat dalam pengadaan dan alokasi sumber daya,

2. Efisiensi: Berdaya guna dalam penggunaan sumber daya,

3. Efektivitas: berhasil guna dalam arti mencapai tujuan dan sasaran.

\subsubsection{Tujuan Sistem Akuntansi}

Dalam mewujudkan sistem akuntansi yang baik, pada dasarnya harus mengetahui pembangun sistem akuntansi itu sendiri, sistem akuntansi erat hubungannya dengan kerjasama manusia dengan sumber daya lainnya didalam suatu perusahaan untuk mewujudkan tujuan perusahaan. Tujuan sistem akuntansi merupakan suatu tujuan yang berdasarkan tujuan yang ingin dicapai oleh perusahaan.

Dari setiap sistem akuntansi yang terdiri dari berbagai sistem mempunyai tujuan yang sama, sistem akuntansi sendiri dibuat oleh manajemen dalam mengelola perusahaannya, maka dari itu untuk lebih jelasnya, tujuan sistem akuntansi dapat dikemukakan dibawah ini.

Tujuan sistem akuntansi yang dikemukakan oleh Mulyadi dalam bukunya Sistem Akuntansi (2001). Tujuan umum pengembangan sistem akuntansi mempunyai tujuan utama sebagai berikut :

1. Untuk menyediakan informasi bagi pengelolaan kegiatan usaha baru

2. Untuk meningkatkan informasi yang dihasilkan oleh sistem yang sudah ada, baik mengenai mutu, ketepatan penyajian, maupun struktur informasinya 
3. Untuk memperbaiki pengendalian akuntansi dan pengecekkan intern, yaitu untuk memperbaiki tingkat keandalan (reability) informasi akuntansi, dan untuk menyediakan catatan lengkap mengenai pertanggungjawaban dan perlindungan kekayaan perusahaan

4. Untuk mengurangi biaya klerikal dalam penyelenggaraan catatan akuntansi.

Dari uraian tujuan sistem akuntansi diatas, dapat disimpulkan bahwa sistem akuntansi merupakan faktor utama pendorong agar manajemen perusahaan dapat menghasilkan informasi akuntansi yang terstruktur dan mengandung arti.

\subsubsection{Teori Pengembangan Sumber Daya Manusia}

Pada hakekatnya pengembangan sumber daya manusia mempunyai dimensi luas yang bertujuan meningkatkan potensi yang dimiliki oleh sumber daya manusia, sebagai upaya meningkatkan profesionalisme dalam organisasi (Wayne dan Awad, 1981:29). Pengembangan sumber daya manusia yang terarah dan terencana disertai pengelolaan yang baik akan dapat menghemat sumber daya lainnya atau setidak-tidaknya pengolahan dan pemakaian sumber daya organisasi dapat secara berdaya guna dan berhasil guna. Pengembangan sumber daya manusia merupakan keharusan mutlak bagi suatu organisasi dalam menghadapi tuntutan tugas sekarang maupun dan terutama untuk menjawab tantangan masa depan (Siagian, 1996). Kondisi "conditio sine quanon" ini dapat dikategorikan sebagai bentuk investasi yaitu human investasi. Meskipun program orientasi pengembangan ini memakan waktu dan dana, semua organisasi mempunyai keharusan untuk melaksanakannya, dan menyebut biaya-biaya untuk berbagai program tersebut sebagai investasi dalam sumber daya manusia. Sesungguhnya tujuan latihan atau tujuan pengembangan pegawai yang efektif, untuk memperoleh tiga hal yaitu : (1) menambah pengetahuan; (2) menambah ketrampilan; (3) merubah sikap.

Pengembangan dilakukan untuk menutup "gap" antara kecakapan atau kemampuan karyawan dengan permintaan jabatan. Kedua, program tersebut diharapkan dapat meningkatkan efisiensi dan efektivitas kerja karyawan dalam mencapai sasaran-sasaran kerja yang ditetapkan. (Handoko, 1998). Pencapaian keselarasan tujuan tersebut tentunya harus ditempuh melalui suatu proses tahapan panjang yang dimulai dari perencanaan sampai dengan pengelolaan dan pemeliharaan potensi sumber daya manusia. Karena secara makro Pengembangan sumber daya manusia (human resourses development) merupakan suatu proses peningkatan kualitas atau kemampuan manusia, yaitu mencakup perencanaan, pengembangan dan pengelolaan sumber daya manusia (Notoatmodjo, 1998).

\subsection{Penelitian Terdahulu}

Penelitian mengenai Standar Akuntansi Berbasis Akrual yang dilakukan oleh beberapa peneliti sebelumnya memiliki beberapa persamaan dan perbedaan dengan penulisan saat ini antara lain; Persamaa penelitian yang dilakukan oleh Andi, Mazudiarif, dan Ririz yaitu sama-sama meneliti tentang kesiapan pemerintah daerah dalam menerapkan Standar Akuntansi Berbasis Akrual dengan menggunakan metode kualitatif yang bertujuan untuk mengetahui sejauh mana kesiapan pemerintah daerah dalam menerapkan Standar Akuntansi Berbasis Akrual dengan melakukan observasi lapangan terlebih dahulu, setelah itu melakukan wawancara kepada beberapa responden kunci. Hanya saja pada penulisan saat ini berfokus juga kepada kesiapan pengembangan SDM terkait dengan penerapan Standar Akuntansi Berbasis Akrual . 


\section{KERANGKA KONSEPTUAL}

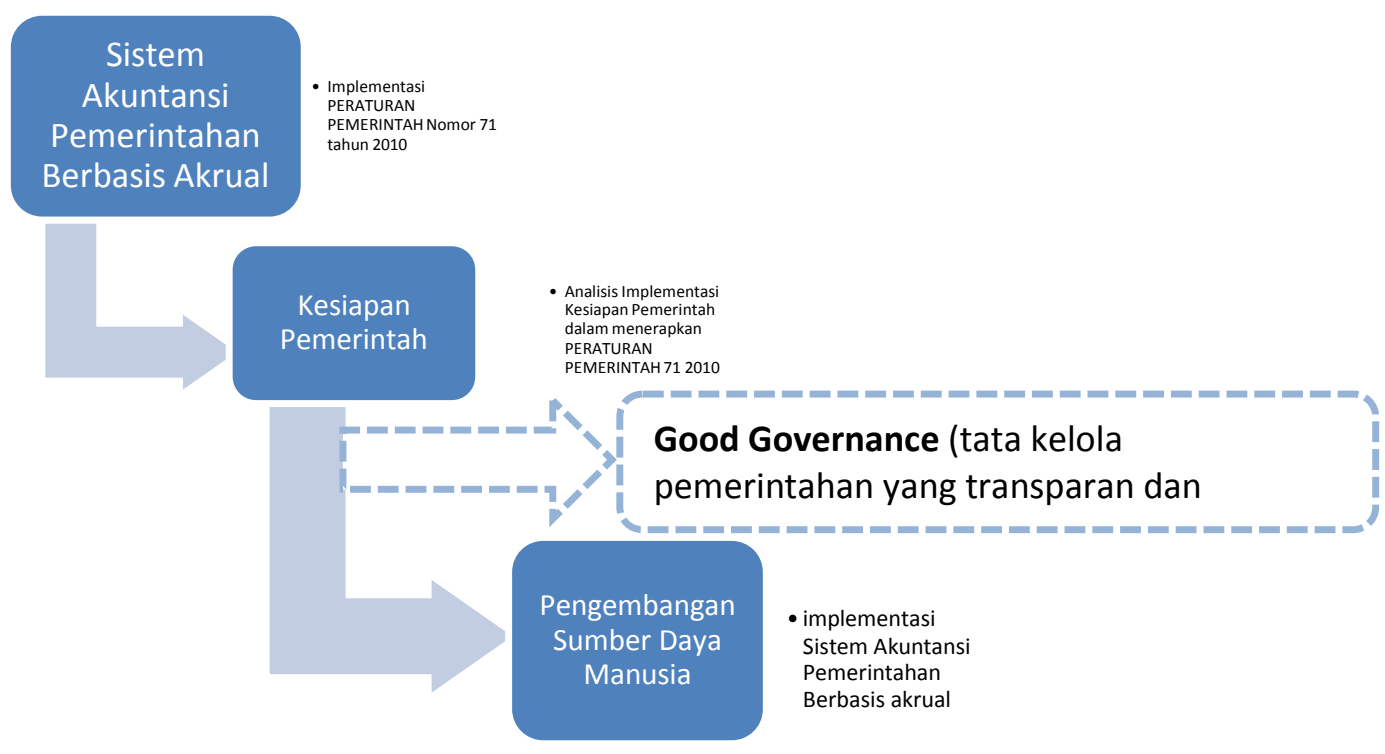

\section{METODE PENELITIAN}

\subsection{Jenis Penelitian}

Jenis penelitian ini adalah kualitatif dengan menggunakan metode Focus Group Discussion. Menurut McMillan \& Schumacher (2003) Penelitian kualitatif adalah suatu pendekatan yang disebut pendekatan investigasi karena biasanya peneliti mengumpulkan data dengan cara bertatap muka langsung dan berinteraksi dengan orang-orang di tempat penelitian.

Penelitian kualitatif juga bisa dimaksudkan sebagai jenis penelitian yang temuan-temuannya tidak diperoleh melalui prosedur statistik atau bentuk hitungan lainnya ( Strauss \& Corbin, 2003).

Sementara itu, menurut Sugiono (2009), metode penelitian kualitatif adalah metode penelitian yang berlandaskan pada filsafat postpositifsime, digunakan untuk meneliti pada kondisi objek yang alamiah (sebagai lawannya adalah eksperimen) dimana peneliti adalah sebagai instrument kunci, pengambilan sampel sumber dan data dilakukan secara purposive dan snowbaal, teknik pengumpulan data dilakukan dengan triangulasi (gabungan) analisis data bersifat induktif / kualitatif, dan hasil penelitian kualitatif lebih menekankan pada makna daripada generalisasi.

Tentang metode FGD, Hollander (2004), Duggleby (2005), dan Lehoux et al. (2006) mendefinisikan metode FGD sebagai suatu metode untuk memperoleh produk data/informasi melalui interaksi sosial sekelompok individu yang dalam interaksi tersebut, sesama individu saling mempengaruhi satu dengan lainnya. Lebih rinci, Hollander (2004) menjelaskan bahwa interaksi sosial sekelompok individu tersebut dapat saling mempengaruhi dan menghasilkan data/informasi jika memiliki kesamaan dalam hal, antara lain memiliki kesamaan karakteristik individu secara umum, kesamaan status sosial, kesamaan isu/permasalahan, dan kesamaan relasi/hubungan secara sosial.

\subsubsection{Karakteristik Metode Focus Group Discussion}

Metode FGD merupakan salah satu metode pengumpulan data penelitian dengan hasil akhir memberikan data yang berasal dari hasil interaksi sejumlah partisipan suatu penelitian, seperti umumnya metode-metode pengumpulan data lainnya. Berbeda dengan metode pengumpul data lainnya, metode FGD memiliki sejumlah karakteristik, diantaranya, merupakan metode pengumpul data untuk jenis penelitian kualitatif dan data yang dihasilkan berasal dari eksplorasi interaksi sosial yang terjadi ketika proses diskusi yang dilakukan para informan yang terlibat(Lehoux, Poland, \& Daudelin, 2006). Karakteristik pelaksanaan kegiatan FGD dilakukan secara obyektif dan bersifat eksternal. FGD membutuhkan fasilitator/moderator terlatih dan terandalkan untuk memfasilitasi diskusi agar interaksi yang terjadi diantara partisipan terfokus pada penyelesaian masalah. Carey (1994) menjelaskan karakteristik pelaksanaan metode FGD yaitu menggunakan wawancara semi struktur kepada suatu kelompok individu dengan seorang moderator yang memimpin diskusi dengan tatanan informal dan bertujuan mengumpulkan data atau informasi tentang topik isu tertentu. Metode FGD memiliki 
karakteristik jumlah individu yang cukup bervariasi untuk satu kelompok diskusi. Satu kelompok diskusi dapat terdiri dari 4 sampai 8 individu (Kitzinger, 1996; Twin, 1998) atau 6 sampai 10 individu (Howard, Hubelbank,\&Moore,1999).

\subsection{Objek Penelitian}

Penelitian ini dilakukan dengan mengambil objek pada Pemerintah Daerah Kota Bitung. Adapun objek yang diteliti dalam penelitian ini adalah orang-orang yang berhubungan dengan penyusunan laporan keuangan pemerintah daerah (LKPD). Dalam penelitian ini yang menjadi informan adalah orangorang yang dianggap memiliki informasi kunci (keyinforman) yang dibutuhkan di wilayah penelitian, yaitu kepala bagian keuangan, Sekretaris Badan keuangan, Kepala bidang akuntansi, Kepala bidang anggaran , Kepala Bidang akuntansi, Kepala sub bagian keuangan DISPENDA, pegawai pada dinas BPKBMD Bitung serta Sekretaris Daerah Kota Bitung selaku ketua tim anggaran kota Bitung.

Tabel 4.1 Objek Penelitian pada Pemerintah Kota Bitung

\begin{tabular}{|l|l|l|}
\hline Nomor & Nama & Jabatan \\
\hline 1. & Drs. Edison Humiang, MSi & Sekretaris Daerah Kota Bitung \\
\hline 2. & Franky D. Sondakh, SE.Ak, Msi & Kepala BadanKeuangan \\
\hline 3. & Reintje R. Senduk, SE, MSi & Kepala Bidang Anggaran \\
\hline 4. & Ricky Layata, SE,Ak MAP & Kepala Bidang Akuntansi \\
\hline 5. & Ekawati, S.Sos & $\begin{array}{l}\text { Kepala Sub. Bagian Keuangan } \\
\text { DISPENDA }\end{array}$ \\
\hline
\end{tabular}

\subsubsection{Tahapan Penelitian}

Penelitian ini diawali dengan kegiatan observasi. Kegiatan observasi ini dimaksudkan untuk mengidentifikasi permasalahan yang terjadi di masyarakat. Observasi ini dilakukan untuk mengetahui apakah penelitian bisa dilakukan atau tidak. Setelah observasi dilakukan dan diperbolehkan mengadakan penelitian, maka langkah yang kemudian dilakukan adalah membuat rencana skripsi. Dengan terlebih dahulu membuat permohonan ijin penelitian ke tempat penelitian. Langkah-langkah penelitian selanjutnya diawali dengan mempersiapkan instrumen pendukung seperti daftar wawancara dan alat perekam untuk melaksanakan wawancara terhadap sejumlah informan. Wawancara dilakukan dengan orang-orang yang berhubungan dengan penyusunan laporan keuangan pemerintah daerah Kota Bitung.

Setelah wawancara dilakukan, langkah selanjutnya adalah mengumpulkan data, kemudian menganalisis data dengan teknik analisis Miles dan Huberman (1992) dalam Sugiyono (2010) untuk dibuat laporan penelitiannya. Peneliti akan menganalisis hasil wawancara dan diskusi dengan menggunakan teori budaya, yaitu secara aktif menginterpretasikan hasil diskusi grup yang terkumpul terkait dengan perubahan budaya mengenai peralihan penggunaan standar akuntansi pemerintahan dari basis kas menuju akrual kebasis akrual penuh sesuai dengan apa yang didapat oleh peneliti dalam proses penelitiannya. Setelah itu, disusun pembahasan dari hasil penelitian dan dibuat kesimpulan yang didapat dari hasil penelitian tersebut.

\section{ANALISIS DAN PENERAPAN HASIL PENELITIAN}

\subsection{Kesiapan Penerapan Standar Akuntansi Berbasis Akrual Pada Pemerintah Kota Bitung}

Kehadiran Peraturan Pemerintah Nomor 71 tahun 2010 tentang Standar Akuntansi Pemerintahan, berbuah keputusan penghapusan Standar Akuntansi Pemerintahan Berbasis Kas menuju Akrual dan Penerapan Standar Akuntansi Pemerintahan Berbasis Akrual secara penuh harus mulai di tahun 2015. Sebagaimana disebutkan dalam Peraturan Pemerintah nomor 71 tahun 2010 pasal 1 ayat (8) bahwa yang dimaksud dengan SAP berbasis akrual adalah standar akuntansi pemerintahan yang mengakui pendapatan, beban, aset, utang, dan ekuitas dalam pelaporan finansial berbasis akrual, serta mengakui pendapatan, belanja, dan pembiayaan dalam pelaporan pelaksanaan anggaran berdasarkan basis yang ditetapkan dalam APBN atau APBD.

Badan pengelola keuangan dan Barang Milik Daerah pemerintah Kota Bitung ketika dipertanyakan tentang kesiapan pemerintah Kota Bitung dalam menerapkan standar akuntansi 
pemerintahan berbasis akrual, mereka sudah matang akan kesiapan dari basis akrual itu sendiri. Responden 1 selaku kepala Badan Pengelola Keuangan dan Barang Milik Daerah melihat : "Sebenarnya persiapannya kita sudah mulai, namun ditahun persiapan yang lebih intens itu 2014 karena ketika keluarnya Peraturan Menteri Dalam Negeri 64 tahun 2013 begitu juga sebagaimana amanah Peraturan Pemerintah Nomor 71 tahun 2010 paling lambat untuk penerapannya Pearturan Pemerintah Nomor 71 sudah harus jalan di tahun 2015 memang terkait dengan persiapan sebagaimana amanat Peraturan Menteri Dalam Negeri Nomor 64 Tahun 2013 sudah harus jalan di 2015 ini karena itu ditahun 2014 sebagaimana amanat Permendagri itu diamanatkan agar semua daerah harus menyusun kebijakan akuntansi paling lambat 31 Mei 2014 dan itu sudah dilakukan oleh pemerintah kota Bitung, jadi persiapan terkait dengan pelaksanaan akrual itu sementara dilakukan dan sebetulnya paling inti adalah ketika kita melakukan restatement, adanya perbedaan perlakuan antara perlakuan akuntansi untuk Pearturan Pemerintah Nomor 24 tahun 2005 dengan Peraturan Pemerintah Nomor 71 tahun 2010 ketika ada perbedaan perlakuan diakomodir lewat restatement dan ini sementara dilakukan oleh pemerintah Kota. Misalnya tahun kemarin di Peraturan Pemerintah nomor 24 tahun 2005, sudah ada penyusutan tetapi kita belum lakukan, namun di restatement itu yang kita ungkap terkait dengan misalnya piutang, itu diungkap semua supaya itu jadi titik awal untuk kita mengimplementasikan Peraturan Pemerintah Nomor 71 tahun 2010 standar akuntansi berbasis akrual".

Pernyataan responden diatas telah sesuai dengan Peraturan Menteri Dalam Negeri Nomor 64 Tahun 2013 tentang Penerapan Akuntansi Pemerintahan Berbasis Akrual pada Pemerintah daerah yang diterbitkan pada tanggal 3 Desember 2013 oleh Menteri Dalam Negeri mengenai Persiapan Penerapan Akuntansi Pemerintahan Berbasis Akrual ada Beberapa hal yang harus dipersiapkan oleh pemerintah daerah di tahun 2014 sebagaimana diamanatkan dalam Permendagri 64 tahun 2013 satu diantaranya yaitu menetapkan peraturan kepala daerah tentang kebijakan akuntansi pemerintah daerah yang berlaku baik bagi entitas akuntansi maupun entitas pelaporan, dan berdasarkan pernyataan responden peraturan kepala daerah tersebut sudah dibuat pemerintah Kota Bitung.

Responden 1 juga menambahkan penjelasan mengenai pengertian akuntansi berbasis akrual yaitu suatu basis akuntansi di mana transaksi ekonomi dan peristiwa lainnya diakui, dicatat, dan disajikan dalam laporan keuangan pada saat terjadinya transaksi tersebut, tanpa memperhatikan waktu kas atau setara kas diterima atau dibayarkan. Dalam akuntansi berbasis akrual, waktu pencatatan (recording) sesuai dengan saat terjadinya arus sumber daya, kami melihat hal ini berdampak baik karena dapat menyediakan informasi yang paling komprehensif sehingga seluruh arus sumber daya langsung dicatat.

Pandangan responden 1 di atas telah sesuai dengan makna basis akrual seperti yang telah disimpulkan oleh KSAP (2006), yaitu suatu basis akuntansi di mana transaksi ekonomi dan peristiwa lainnya diakui, dicatat, dan disajikan dalam laporan keuangan pada saat terjadinya transaksi tersebut, tanpa memerhatikan waktu kas atau setara kas diterima atau dibayarkan.

\subsubsection{Komitmen Pemerintah Kota Bitung}

Pernyataan yang mendukung komitmen pimpinan pemerintah kota Bitung dalam penerapan basis akuntansi ini disampaikan oleh Responden 4 selaku Kabag Anggaran Kota Bitung: "seperti yang telah dijelaskan sebelumnya, Pemkot Bitung mengikuti aturan pedoman penyusunan APBD yang sudah menganggarkan untuk penerapan akrual walaupun 2014 belum secara spesifik ditulis untuk akrual, tapi sudah ditingkatkan PAGU anggarannya dalam rangka mendukung implementasi SAP ini. Dan untuk tahun 2015 demikian juga oleh pemerintah kota Bitung diharuskan juga menganggarkan hal tersebut dan itu sudah spesifik kalo kita perhatikan APBD 2015 sudah ada mata anggaran untuk bimbingan teknis SAP Akrual . Jadi sudah spesifik menyebut untuk persiapan akrual”.

Berdasarkan pernyataan tersebut dapat disimpulkan bahwa komitmen dan dukungan dari para pengambil keputusan di pemerintah Kota Bitung sudah sepenuhnya, karena pemkot Bitung menyadari upaya penerapan akuntansi berbasis akrual memerlukan dana yang besar dan waktu yang lama sehingga dukungan dan komitmen dari pemerintah sangatlah penting. 


\subsubsection{Sumber Daya Manusia}

Sumber Daya Manusia merupakan pilar penyangga utama sekaligus penggerak roda organisasi dalam usaha mewujudkan visi dan misi serta tujuan dari organisasi. Kegagalan sumber daya manusia Pemerintah Daerah dalam memahami dan menerapkan logika akuntansi akan berdampak pada kekeliruan laporan keuangan yang dibuat dan ketidaksesuaian laporan dengan standar yang ditetapkan pemerintah (Warisno dalam Putri, 2010). Selain itu, menurut Bastian (2006), pada saat ini, kebutuhan tersebut sangat terasa dengan semakin kuatnya upaya untuk menerapkan akuntansi pemerintahan berbasis akrual.

Untuk itu, pemerintah pusat dan daerah perlu secara serius menyusun perencanaan SDM di bidang akuntansi pemerintahan. Termasuk di dalamnya memberikan system insentif dan remunerasi yang memadai untuk mencegah timbulnya praktik korupsi, kolusi, dan nepotisme (KKN) oleh SDM yang terkait dengan akuntansi pemerintahan.

\subsubsection{Sarana dan Prasaran Sistem Informasi Akuntansi}

Selain itu penerapan basis akrual juga ditentukan oleh sistem yang digunakan. Hal ini tentu saja membutuhkan biaya dan waktu yang tidak sedikit untuk dapat mewujudkannya. Menurut Cushing dan Kosasih (1989) sistem informasi akuntansi didefinisikan sebagai kumpulan manusia dan sumber-sumber modal didalam suatu organisasi yang bertanggung jawab untuk menyiapkan informasi keuangan dan juga informasi yang diperoleh dari pengumpulan dan pengolahan data transaksi.

Pemerintah Kota Bitung melalui Responden 1 selaku Kepala BPKBMD kota Bitung menyatakan : "Terkait dengan pelaksanaan Peraturan Pemerintah Nomor 71 tahun 2010 di pemerintah kota Bitung menggunakan tools SIMDA versi 2.7, SIMDA adalah produk dari BPKP. Kita sudah lama menggunakan software ini dari tahun 2007 dari masih Peraturan Pemerintah 24 sampai dengan sekarang. Memang untuk menghadapi akrual ini dari BPKP telah menyesuaikan dengan Peraturan Pemerintah Nomor 71 tahun 2010 sehingga dikeluarkannya SIMDA versi 2.7 yang mengakomodir pelaporan keuangan terkait dengan Peraturan Pemerintah Nomor 71 tahun 2010 atau standar akuntansi berbasis akrual".

\subsection{Dampaknya Terhadap Pengembangan Sumber Daya Manusia}

Keberadaan aparatur pemerintah tidak bisa dilepaskan dari tugas pokok yang diemban oleh Pemerintah, yaitu melayani masyarakat. Tugas pelayanan ini menekankan upaya mendahulukan kepentingan umum dan memberikan kepuasan kepada publik. Dalam pelaksanaan tugas pemerintah, prinsip-prinsip yang terkandung dalam tata pemerintahan yang baik (good governance) merupakan acuan bagi terselenggaranya pemerintahan yang dapat bersinergi dengan masyarakat, dalam rangka pelaksanaan pelayanan publik yang optimal. Saat dipertanyakan mengenai peranan SDM dilingkungan Pemerintah responden 2 selaku Sekretaris Kota Bitung menyatakan : "Pemerintah Kota Bitung berusaha untuk mewujudkan suatu tatanan pemerintahan yang selalu tanggap terhadap perkembangan dan tuntutan aspirasi masyarakat dengan dukungan dari aparatur yang memiliki profesionalitas dan prestasi kerja berdasarkan pendidikan dan pelatihan yang memadai, sehingga keberadaan sumber daya manusia yang berkualitas ini akan sangat menentukan kemampuan aparatur yang bersangkutan untuk mengimplementasikan prinsip-prinsip good governance dalam penyelenggaraan pemerintahan dan pelayanan publik seperti contoh juga untuk menerapkan perubahan Peraturan Pemerintah Nomor 24 tahun 2005 ke Peraturan Pemerintah Nomor 71 tahun 2010 yaitu Standar Akuntansi Akrual”.

Pernyataan responden tersebut menjelaskan bahwa dengan kualitas staf bagian keuangan yang lebih baik, diharapkan pelatihan dan lokakarya terkait dengan peningkatan kualitas pelaporan keuangan (misalnya lokakarya untuk memperkenalkan Akuntansi Pemerintahan Berbasis Akrual) akan lebih efektif. Sehingga pengembangan SDM dilingkungan pemerintahan dalam rangka menerapkan APBA akan melahirkan Staf yang mempunyai pengetahuan akuntansi yang cukup dan membuat mereka lebih mudah memahami perubahan basis 'cash towards accrual' ke basis 'accrual'. Kemudian, pelatihan pada staf yang sudah mempunyai latar belakang pengetahuan di bidang akuntansi diharapkan bisa mengurangi secara signifikan berbagai masalah dalam penyusunan laporan keuangan. 


\subsection{Kesimpulan}

Berdasarkan analisis hasil observasi, wawancara dan diskusi dengan key informan dilingkup Pemerintah kota Bitung untuk kesiapan Standar Akuntansi Berbasis akrual sudah dipersiapkan sejak tahun 2014. Bentuk persiapan pemerintah Kota Bitung antara lain :

1. Dari segi mempersiapkan SDM pemerintah mengadakan pelatihan atau bimbingan teknis kepada pegawai yang terkait dengan pelaksanaan standard akuntansi berbasis akrual yang didampingi langsung oleh BPKP.

2. Dari segi komitmen pimpinan, adanya penganggaran untuk pelaksanaan akrual, kemudian merevisi Peraturan Pemerintah daerah yang meliputi peraturan daerah, pokok-pokok pengelolaan keuangan daerah dan peraturan kepala daerah mengenai kebijakan akuntansi serta sistem dan prosedur pengelolaan keuangan daerah pemerintah Kota Bitung,

3. Dari segi sarana dan prasarana sistem informasi, Pemerintah kota Bitung menggunakan produk software dari BPKP yaitu SIMDA versi baru 2.7 yang sudah bisa mengakomodir terkait Standar Akuntansi Berbasis Akrual.

Berdasarkan 3 indikator kesiapan diatas maka dapat disimpulkan bahwa Pemerintah kota Bitung telah siap menerapkan Standar Akuntansi Pemerintahan Berbasis Akrual.

\subsection{SARAN}

Peraturan-peraturan teknis terkait Standar Akuntansi Berbasis Akrual yang telah ditetapkan pemerintah dalam hal ini Kementerian Keuangan dapat dijadikan acuan pelaksanaan akuntansi akrual bagi pemerintah kota Bitung. Selain itu untuk mendukung penerapan Akuntansi Berbasis Akrual di Pemerintah Kota Bitung, Pemerintah dapat melakukan beberapa hal dibawah ini:

1. Menentukan daerah percontohan sebagai upaya menciptakan benchmarking sebelum pada akhirnya dapat digunakan oleh pemerintah Kota Bitung.

2. Sosialisasi dan pelatihan yang berjenjang. Berjenjang yang dimaksud meliputi pimpinan level kebijakan sampai dengan pelaksana teknis, dengan tujuan sosialisasi dan pelatihan untuk meningkatkan skill pelaksana, membangun kesadaran (awareness), dan mengajak keterlibatan semua pihak.

\section{DAFTAR PUSTAKA}

Forum Dosen Akuntansi Sektor Publik, 2006. Standar Akuntansi Pemerintahan, Telaah Kritis Peraturan Pemerintah Nomor 24 Tahun 2005. BPFE. Yogyakarta.Hoesada, Jan. 2010.

Accrual Budgeting and Accrual Accounting pada Pemerintahan NKRI. Jurnal Akuntansi/Tahun XIV, Nomor 01, Januari 2010: 113-124.

International Public Sector Accounting Standards Board. 2011. Transition to the Accrual Basis of Accounting: Guidance for Public Sector Entities, Study 14. Third Edition, IFAC. New York, USA.

Komite Standar Akuntansi Pemerintahan. 2006. Memorandum Pembahasan Penerapan Basis Akrual dalam

Akuntansi Pemerintahan di Indonesia. Bahan Bahasan untuk Limited Hearing. Jakarta.

Mardiasmo. 2009. Akuntansi sektor publik. Penerbit Andi. Yogyakarta.

Mulyana, Budi. Penggunaan Akuntansi Akrual di Negara-Negara Lain: Tren di Negara-Negara Anggota

OECD.

Peraturan Pemerintah Republik Indonesia Nomor 24 Tahun 2005 Tentang Standar Akuntansi Pemerintahan.

Peraturan Pemerintah Republik Indonesia Nomor 71 Tahun 2010 Tentang Standar Akuntansi Pemerintahan.

Ritonga, Rahmansyah. Kas Basis Vs Akrual Basis. Widyaiswara BDK. Medan.

Simanjuntak, Binsar. 2010. Penerapan Akuntansi Berbasis Akrual di Sektor Pemerintahan di Indonesia.

Disampaikan padaKongres XI Ikatan Akuntan Indonesia. Jakarta.

Undang-Undang Republik Indonesia Nomor 1 Tahun 2004 Tentang Perbendaharaan Negara.

Undang-Undang Republik Indonesia Nomor 15 Tahun 2004 Tentang Pemeriksaan Pengelolaan dan

Tanggungjawab Keuangan Negara.

Undang-Undang Republik Indonesia Nomor 17 Tahun 2003 Tentang Keuangan Negara. 
Bastian,Indra,2006, Akuntansi Sektor Publik:Suatu Pengantar,Jakarta,Erlangga.

Bodnar, George H, and William S.Hopwood. 2002. Sistem Informasi. Akuntansi,

Buku I. Jakarta: Penerbit salemba empat,Bungin,Burhan. 2008.Penelitian kualitatif:Komunikasi, Ekonomi,

Kebijakan Publik,dan Ilmu Sosial Lainnya. Jakarta: Kencana

Hartanto, Jogiyanto. 2002. Pengenalan Komputer, Andi,Yogyakarta.

Hasibuan, S.P. Malayu. 2002. Organisasi dan Motivasi. Jakarta : Bumi Aksara

Kieso,Donald E. Dkk. Akuntansi Intermediate, Edisi Keduabelas, Jilid 1, Terjemahanoleh Emil Salim. 2008. Jakarta: Penerbit Erlangga

Mardiasmo.2002.Otonomi Daerah Sebagai Upaya Memperkokoh 